\title{
Pendekatan Psikologis Dalam Upaya Manajemen Konflik Agama
}

\author{
Mercy W.K Waney¹, Mariana Lusye Marlyn Lausan², Gabriela Rantung ${ }^{3}$ \\ 1,2,3Institut Agama Kristen Negeri Manado \\ email: waneymwk@iakn-manado.ac.id
}

ABSTRACT: This study uses a descriptive qualitative approach. The purpose of this study is to find out how the psychological approach of religion in conflict management efforts. In religious life, living in peace is a very important part. Even though it is realized that religion is often used to show radicalism and intolerance. Religion, which is universal in nature, is understood as a concept, experience and actualization of espoused values. Religion is expected to provide a solution to the problems of the soul of its adherents because the values contained include mutual respect and respect. Through a religious psychology approach, we can see the resolution of a conflict.

Keywords: Psychology, Religion, and Conflict Management.

\section{PENDAHULUAN}

Agama adalah suatu bentuk pengakuan terhadap adanya kuasa yang transenden, yang ilahi, yang lebih besar, yang lebih hebat dari manusia. Kuasa itu dipahami sebagai kekuatan supranatural yang tidak dapat dijangkau oleh kemampuan manusia sehingga menimbulkan ketundukkan manusia atau ketaklukan diri pada kuasa tersebut. Dengan berbagai cara dan upaya manusia lakukan untuk menunjukkan kepatuhannya dan mengharapkan keselamatan. Keyakinan ini menghasilkan pengalaman atas keyakinan yang terwujud dalam kehidupan praksis yang pada konteks masyarakat agama. Oleh karena itu, agama memiliki hubungan yang sangat kompleks dimana setiap jiwa memerlukan adanya sentuhan secara spiritual dan dalam psikologi sebagai ilmu yang menguraikan berbagai kehidupan mental. (William James, 1980).

Istilah psikologi dalam bahasa Inggris yakniPsychology, berasal dari bahasa Yunani Psyche yang berarti jiwadan Logos yang berarti ilmu pengetahuan. Hal ini diartikan sebagai ilmu yang mempelajari tentang "jiwa". Dengan kata lain, psikologi mempelajari dan mengkaji semua pengalaman keagamaan: proses, pengaruh, perilaku, gejala, serta relasi dengan Tuhannya yang ditunjukkan dalam kehidupan bermasyarakat. 
Dalam perkembangannya, psikologi meneliti berbagai pengaruh yang ditunjukkan baik itu dalam cara berfikir dan bersikap, serta berkreasi seseorang yang tidak dapat dipisahkan dari keyakinan pada agamanya. Kepribadian seseorang tidak lepas dari sifat agamaisnya.

Kita akan melihat sejarah psikologi agama, berbagai metode dalam mengkaji pengalaman keberagaman, dan objek pada psikologi agama melalui penelitian ini. Pada pendahuluan memberikan suatu kajian terhadap orientasi dan sikap keagamaan, , kematangan, psikologi agama dan kecerdasan spiritual. Setelah dipahami maka kemudian kita melihat hubungannya dengan resolusi konflik.Dalam membangun perdamaian, agama seharusnya menjadi suatu kekuatan yang berfungsi untuk mencegah terjadinya konflik tapi juga menjadi agen-agen pendamaian. Tugas ini bukanlah suatu tugas yang mudah dalam menyelesaikan berbagai masalah yang berhubungan dengan konflik agama. Maka perlu menggunakan pendekatan tidak hanya dari segi agama tapi juga psikologi atau yang disebut psikologi agama.

Manajemen konflik merupakan salah satu dari bagian pendekatan psikologi. Manajemen Konflik memungkinkan situasi atau keadaan dapat dikelola dengan berbagai metode untuk menyelesaikan konflik baik secara individu maupun kelompok. Dalam psikologi melihat konflik itusendiri dalam Psikologi klinis. Umumnya orientasi mengacu pada suatu Proses Pengarahan ke dalam bentuk komunikasihubungan tingkah laku dari dalam maupun pihak luar dengan melihat cara seseorang tersebut dapat mempengaruhi kepentingan dan juga intrepretasi.

Agama yang memiliki daya dukung dalam menyelamatkan dan merekat hubungan, tapi yang bisa juga berpotensi sebagai sumber konflik apabila agama tidak dapat menjawab kebutuhan "jiwa" atau kerohanian penganutnya termasuk dalam penetapan dan penyelesaian terhadap berbagai masalah yang terjadi.

\section{a. Sejarah Perkembangan Psikologi Agama}

Wilhelm Wundt dikenal sebagai seorang psikolog dan fisiolog serta orang pertama yang mengaku dirinya sebagai psikolog. Ia dianggap sebagai bapak psikologi.Pada akhir abad ke - 19 terjadilah babak baru dalam sejarah psikologi. Pada tahun 1879,Wilhem Wundt mendirikan laboratorium pertama di University of leipzigJerman yang menandai titik awal psikologi sebagai suatu ilmu yang berdiri sendiri. Dia juga memperkenalkan metode instropeksi yang digunakan dalam eksperimen - eksperimennya.Seiring berjalannya waktu,psikologi kian berkembang dan menjadi kajian agama untuk membantu cara bertingkah laku manusia mengenai pemahaman terhadap agama.

Saat itu William James,diundang untuk memberikan kuliah di Yayasan Gifford di Universitas Edinburgh.William James meyakini bahwa melalui kajiannya,ia mampu mengembangkan psikologi agama.Kemudian pada tahun 1903 terbitlah karya yang berjudul The Varieties of Religius Experience.Setelah itu pada abad ke-19 terbitlah karya 
yang berjudul The Psychology of Religion yang merupakan kajian paling awal di antara sejumlah penelitian kualitatif.

Sesuatu yang bersifat supernatural juga tidak terlepas dengan kemunculan psikologi agama.Sehingga melalui beberapa pernyataan dari para ahli,maka mereka melihat hubungan tersebut dari sudut pandang psikologi.Para ahli menilai bahwa kepercayaan seseorang juga mempengaruhi faktor kejiwaannya.Untuk mengkaji proses dan hubungan antara kejiwaan seseorang dan kepercayaannya,dapat dilakukan secara empiris dengan menggunakan pendekatan psikologis.

Setelah psikologi diakui sebagai disiplin ilmu yang otonom, para ahli menyatakan bahwa masalah yang bersangkutan dengan batin manusia,ada kaitannya dengan psikologi.Hubungan antara kesadaran agama dan tingkah laku agama dapat dipelajari melalui pendekatan psikologi.Kemudian R.Golmen mengadakan studi perkembangan mengenai konseptual dalam pemikiran anak-anak,dan pemikiran magis pada anak-anak yang didapat dari hasil penelitian A.Godin dan Soeur Marthe.

Seiring berjalannya waktu,psikologi agama pun mulai mendapat perhatian khusus yang menjadi disiplin otonom dengan nama psikologi agama.Pernyataan yang diungkapkan oleh Robert H.Thouless mengenai jumlah penelitian permasalahan khusus psikologi agama yang sudah semakin banyak itu,menginformasikan bahwa psikologi agama semakin penting dalam proses pengkajian tingkah laku agama. Untuk memastikan kapan agama diteliti secara psikologi memang sulit, karena dalam agama memang sudah terkandung di dalamnya ada pengaruh agama terhadap jiwa.Bahkan dalam Kitab suci setiap agama sudah diterangkan bahwa keadaan jiwa seseorang berpengaruh dengan agama-nya.

Yahya Jaya mengatakan babakan lahirnya keilmuan psikologi agama dimulai dari perjumpaan psikologi dan agama. Hanya kapan waktunya belum menjadi suatu kepastian tapi tuntutan untuk melihat dan mengkaji perilaku manusia telah dimulai sebelum abad ke-20. Dalam sejarah perkembangannya terbagi menjadi empat periode. Pada periode awal atau disebut periode pertama dimulai dengan usaha untuk meneliti dan menganalisa tingkah laku dari manusia dan hewan dengan menggunakan metode eksperimen. Pada masa itu, Wilhelm Wundt mendirikan laboratorium dan menggunakan laboratorium itu untuk penelitiannya.Pada abad ke-19, bidang psikologi mulai mengandeng bidang ilmu yang lain dalam perkembangannya secara khusus memulai dengan mengamati dan melakukan berbagai eksperimen di laboratorium.Diawal abad ke-20, agama telah menjadi perhatian dalam meneliti dan menganalisa tingkah laku manusia. Di periode kedua ini, berbagai kajian dikembangkan dengan menggunakan pendekatan psikologi agamauntuk melihat perilaku beragama. William James, Edwin Starbuck dan James H. Leuba merupakan tokoh- tokoh yang berperan penting dalam melahirkan bidang ilmu psikologi agama (1842-1910).Periode ketiga yang dimulai tahun 1930 sampai tahun 1950-an.Dimasa ini kajian terhadap perilaku beragama mengalami kemerosotan.Psikologimulai mengabaikan aspek agama 
dalam mengembangkan keilmuannya dan mulai menekankan pada positivistik dan behavioristik. Di tahun 1960-an menjadi periode keempat dan terus berlangsung sampai dengan sekarang.Dalam periode ini,pengembangan psikologi mulai berfokus pada usahauntuk menjadikan nilai dan budaya sebagai objek kajian psikologi dan sumber inspirasi dalam pembangunan teori-teori psikologi selanjutnya.

\section{b. Objek Kajian}

Robert H. Thouless mengemukakan pendapatnya bahwa,psikologi agama merupakan salah satu cabang dari psikologi yang tujuannya untuk mengembangkan pemahaman terhadap perilaku keagamaan dengan cara mengaplikasikan prinsipprinsip psikologi yang dipungut dari kajian terhadap perilaku manusia dan bukan dari unsur keagamaan. Perilaku seseorang yang terjadi karena adanya pengaruh dari keyakinan yang dianut oleh individu tersebut adalah salah satu kajian dalam psikologi agama. Bahwa Gejala keagamaan dapat dijelaskan melalui ilmu jiwa. Ahmad Saifuddin menyimpulkan bahwa pada psikologi agama, kejiwaan individuyang utuh sebagai manusia yang menjalankankeagamaannya tidak hanya dipelajari tapi juga dikaji pengaruhnya pada kesehatan kejiwaan. Contoh konkrit yang sehat mental dan jiwanya adalah disaat kita bertemu dengan orang lain kemudian kita mengucapkan salam dan menunjukkan rasa hormat kepada orang tua dan orang lain. Meskipun ada perbedaan manifestasi dalam pengalaman beragama,namun pengalaman beragama ini merupakan fase pengembangan seseorang yang muncul sejak masih anak-anak disaat mengalami berbagai problem yang kemudian membebaskannya karena adanya eksistensi dalam diri seseorang,agar ia dapat merasakan sesuatu yang ada dari luar dirinya.

Dari berbagai bentuk kegiatan yang dilakukan oleh setiap individu melalui interaksi antar pemeluk agama,kemudian realitas dijadikan sebagai manifestasi yang berasal dari bentuk keyakinan beragama yang berasal dari para pemeluknya.

Melalui beberapa penjelasan di atas,ada beberapa objek kajian agama yang diklasifikasikan yaitu antara lain:

1. Psikologi Agamayaitu objek pembahasannya mengenai bagaimana proses perkembangan seseorang terhadap kepercayaannya kepada Tuhan sejak ia masih anak-anak sampai sudah dewasa.Selain itu ada juga pembahasan mengenai kapan kematangan beragama setiap individu serta adanya perbedaan tingkah laku setiap individu yang memiliki keyakinan untuk beragama dan yang tidak memiliki keyakinan untuk beragama.

2. Contoh tindakan yang dilakukan untuk menunjukkan kesadaran yang ada dalam diri seseorang serta dalam pemikiran dan dalam hati yang kemudian dimanifestasi dalam sebuah tindakan, yaitu melaksanakan ibadah. Dari situ muncullah pengalaman beragama yang dimunculkan dari aspek perasaan,contohnya rasa damai dan tenang.Setelah itu terjadilah proses psikologis yang ditunjukkan melalui terjadinya perilaku keagamaan seseorang yang akhirnya muncul pengaruh agama terhadap perilaku individu tersebut. 
3. Rasa lega dan rasa tentram yang muncul disaat kita selesai berdoa dan merasakan kelegaan batin sesudah membaca dan merenungkan Firmanyang ada pada kitab suci masing-masing agama yang kita anut,disebut sebagai macammacam emosi yang muncul dari luar kesadaran diri kita dalam kehidupan beragama.

4. Mengkaji yaitu cara yang dilakukan untuk menganalisis atau mengadakan penelitian mengenai pengaruh kepercayaan pada keadaan yang akan dialami oleh setiap manusia.

5. Rasa tenang dan kelegaan batin,merupakan perasaan dan pengalaman seorang individu terhadap Tuhannya.

\section{C . Psikologi Agama sebagai Upaya Manajemen Konflik Agama}

Walter Houston Clark dalam buku Psychology of Religion,mengatakan ciri-ciri keagamaan yang matang pada setiap individu umumnya, pertama bahwaorang yang matang itu memiliki sikap kritis,kreatif dan mandiri. Kedua,orang tersebut memperluas perhatiannya di luar dari dirinya,contohnya dalam berdoa.Orang tersebut berdoa tidak hanya untuk dirinya sendiri,melainkan ia juga mendoakan orang lain.Contohnya pada orang dewasa,ia juga mendoakan sesama.Ketiga, tidak merasa puas dengan ritual dan verbalitas dari ajaran agamanya.Namun, melalui, ritual dan verbalitas tetaplah menjadi bagian dalam kehidupan mereka disaat menjalankan ajaran agama yang mereka anut,untuk saling menyayangi satu sama lain serta adanya toleransi diantara umat bergama dan saling menghormati ajaran satu sama lain.

Konflik adalah bentuk perasaan yang berbeda atau yang tidak sesuai dari keinginan diantara hubungan individu yang satu dengan yang lain, atau kelompok yang satu dengan kelompok yang lain(Allo Liliweri, 1997). Dalam bukunya tentang manajemen konflik, Winardi menyatakan bahwa konflik itu suatu pertentangan antara kelompok, apakah itu dalam hubungannya dengan perasaan maupun tindakan yang dilakukan tidak disetujui atau tidak diterima oleh kelompok yang lain. James Stoner dan R. Edward Freeman menguraikan manajemen konflik dalam 3 metode. Pertama disebutstimulasi konflik dimana konflik diberikan sebagai suatu rangsangan untuk suatu perubahan yang lebih baik. Kedua, MetodePengurangan Konflikyang tujuannya meredam keadaan atau situasi dengan cara-cara pengelolaan yang menyenangkan keduabelah pihak. Ketiga disebut metode penyelesaian konflik dengan langkah-langkah dominasi, kompromi dan pemecahan masalah.

Berbagai konflik agama tak dapat dihindari selalu terjadi dimana manajemen konflik menjadi salah satu cara dalam meredam konflik agama. Dimulai dari cara mengelola dan sampai pada bagaimana berkolaborasi dalam menyelesaikan permasalahan yang terjadi dibutuhkan kematangan beragama untuk mendapatkan solusi yang bisa diterima oleh pihak yang bertikai. 
Melalui penjelasan-penjelasan di atas,sudah dijelaskan bahwa agama menyajikan konsep kematangan beragama bagi para penganutnya untuk memperkuat kematangan jiwa seseorang dalam beragama. Kematangan tersebut menjadikan individulebih baik, memiliki jiwa penyayang,dan damai yang akan menghadirkan resolusi-resolusi untuk meredam konflik-konflik beragama yang ada. Semakin stabil kematangan jiwa yang dimiliki oleh setiap individu,akan melahirkan perilaku beragama yang damai, yang tidak hanya terbatas pada tahap ritual dan verbal saja,melainkan juga pada aspek pemaknaan yang mendalam.

\section{METODE PENELITIAN}

Pada penelitian ini menggunakan metode kualitatif deskriptif dengan menggunakan dokumen pribadi (personal document) dan Kuesioner dan Wawancara.Tujuan penelitian ini untuk mengetahui bagaimana pendekatan psikologis agama dalam upaya manajemen konflik. Pendekatan psikologi menjadi salah satu upaya dalam menjawab permasalahan agama. Dalam menghadapi konflik agama, manajemen konflik yang akan diterapkan akan lebih terarah dan tepat.

\section{HASIL DAN PEMBAHASAN}

Kematangan dalam beragama akan menjadikan orang tidak dengan mudah menerima dan atau mengambil keputusan terhadap suatu masalah, tetapi selalu bersikap otonom dan kreatif dalam menyelesaikan masalah sehingga kebenaran yang dipegang adalah sebuah perenungan yang mendalam terhadap makna dan ajaran agama.

Hidupnya tidak berfokus pada dirinya sendiri tapi spiritualitasnya membuat dia mampu untuk dapat memberi hidupnya berguna bagi orang lain. Seperti halnya ketika seorang itu berdoa, maka dia tidak hanya berdoa bagi diri sendiri tapi juga keselamatan orang lain termasuk musuhnya (bandingkan dengan bagian Alkitab dalam Matius 5:4445). Orang yang matang keberagamaannya, tidak seperti keagaaman yang kanak-kanak, hanya menjadikan keyakinan dan kasihnya pada Tuhannyaada pada ruang kegiatan ritual agama dan penyampaian ajaranagama tapi terwujud dalam pemaknaan hidup yangnyata dalam tindakan. Perilaku hidup dewasa dan matang adalah kemampuan dalam menghargai dan mengasihi orang lain dengan tulus, mampu menghargai agama lain dan perbedaan yang ada, sikap hidup yang rendah hati sehingga bisa saling menghormati.

Apa yang dipaparkan diatas, memberikan pengetahuan bagi kita bahwa pendekatan psikologi menjadi salah satu upaya dalam menjawab permasalahan agama. Hal ini memberi sumbangsih dalam manajemen konflik baik yang terjadi secara internal maupun eskternal.Dalam menghadapi konflikagama, manajemen konflik yang akan diterapkan akan lebih terarah dan tepat karena melalui pendekatan psikologis, konsep kematangan beragama yang ditawarkan menjadi kekuatan dan daya dorong resolusi terhadap terwujudnya perdamaian. Bahwa semakin matang keberagamaannya, 
semakin dewasa menyikapi berbagai situasi dalam hubungan dengan sesama. Cara pandang terhadap keberagamaan bukan sebagai pemicu konflik tetapi sebagai kekayaan dalam merekatkan berbagai perbedaan untuk bisa hidup yang toleran, dan berkarya bersama.

\section{KESIMPULAN}

Dapat disimpulkan pendekatan psikologi agama adalah usaha melihat, meneliti, mengkaji agama dan dari psikologis memberi pengaruh besar terhadap kehidupan beragama pada setiap orang.Pendekatan psikologi agama mempengaruhi dan menjadi daya dorong resolusi terhadap berbagai konflik agama yang tidak dapat dielakkan. Tetapi juga, menjadi bahan evaluatif terhadap pemaknaan dari nilaiyang dianut.

\section{DAFTAR PUSTAKA}

Arifin, HM. 1976. Psikologi dan Beberapa Aspek Kehidupan Rohaniyah Manusia, Jakarta: Bulan Bintang.

Atkinson, Rita L. dkk. 1993. Instroduction of Psychology, terj. Nurdjanah Taufik dan Rukmini Burhan, Pengantar Psikologi. Jakarta: Penerbit Airlangga.

Carter, Judy and Gordon S. Smith. 2004. Religious Peacebuilding: From Potential to Action, within Harold Coward and Gordon S. Smith (Eds), Religion and Peace Building. Albany: State University on New York Press.

Liliweri Allo. 1997. Komunikasi Antar Pribadi. Bandung: Citra Aditya Bakti.

Faber, Heije, Cirkelen on een Geheim, terj. Margaret Kohl. 1976. Psycohology of Religion. London: SCM Press Ltd.

Freeman R. Edward dan James A.F. Stoner. 2006. Manajemen Jilid 1. Jakarta: Intermedia.

Saifuddin Ahmad. 2019. Psikologi Agama. Jakarta: Prenadamedia.

Suriasumantri, Jujun S.1995. Filsafat Ilmu, Sebuah Pengantar Populer. Jakarta: Pustaka Sinar Harapan.

Sururin 2005. Ilmu Jiwa agama. Jakarta: Rajagrafindo Persa.

Thouless, Robert H. 1992. An Introduction to the Psychology of Religion, trej. Machnun Husein, Pengantar Psikologi Agama. Jakarta: Rajawali Pers. 
Winardi. 1994. Manajemen Konflik: Konflik Perubahan dan Pengembangan. Bandung: Mandar. 